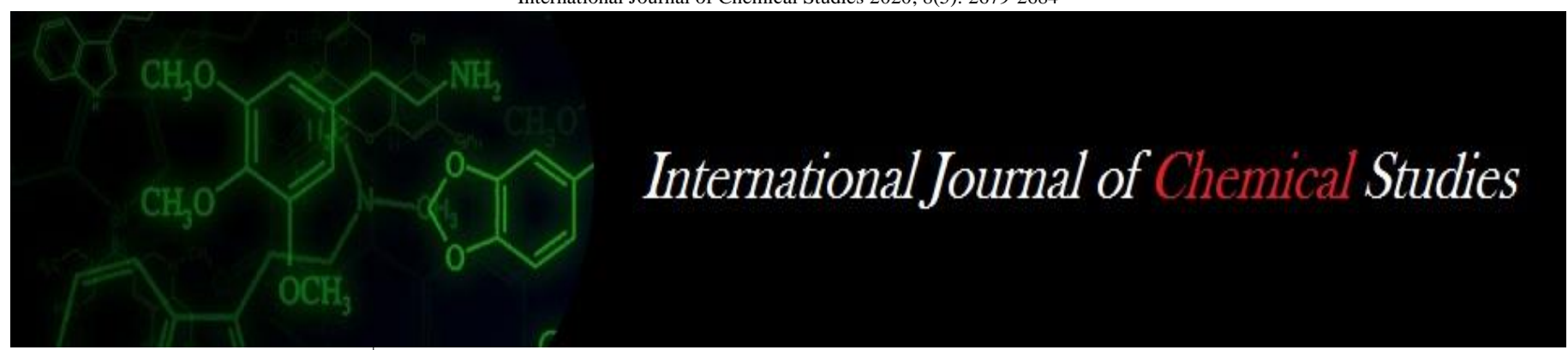

P-ISSN: 2349-8528

E-ISSN: 2321-4902

www.chemijournal.com

IJCS 2020; 8(5): 2679-2684

(C) 2020 IJCS

Received: 22-06-2020

Accepted: 28-07-2020

\section{Mamta Phogat}

Chaudhary Charan Singh

Haryana Agricultural

University, Hisar, Haryana,

India

\section{Rita Dahiya}

Chaudhary Charan Singh

Haryana Agricultural

University, Hisar, Haryana,

India

\section{PS Sangwan}

Chaudhary Charan Singh

Haryana Agricultural

University, Hisar, Haryana,

India

Manchala Santhosh Kumar

Chaudhary Charan Singh

Haryana Agricultural

University, Hisar, Haryana,

India
Corresponding Author: Mamta Phogat

Chaudhary Charan Singh

Haryana Agricultural

University, Hisar, Haryana,

India

\section{Effect of long term zero tillage on soil chemical properties: A review}

\author{
Mamta Phogat, Rita Dahiya, PS Sangwan and Manchala Santhosh \\ Kumar
}

DOI: https://doi.org/10.22271/chemi.2020.v8.i5ak.10722

\begin{abstract}
To feed the rising population on a sustainable basis without degrading natural resources, there is a need to increase farm productivity and total food production. While green revolution technologies implemented in the country during 1966-67 led to food protection, intensive cultivation, insufficient and imbalanced use of fertilisers, high yielding crop varieties, use of heavy machinery, excess tillage, etc., resulted in deterioration of soil health and quality and increased air, soil and water pollution for more than five decades. There is a great lack of a systematic approach to relating tillage practises to chemical soil properties. The most significant pillar of conservation farming is zero tillage. The need for an hour is conservation farming. It is a win-win operation for farmers as well as for the environment. The goal of Tillage was to establish a soil environment conducive to plant growth, but to have negative effects on soil resources, structure and eventually on the environment in the long run. Zero tillage has the ability to enhance the chemical properties and environment of the soil in the long run. Keeping all of these under consideration, this analysis is compiled to create a perfect tillage scheme, i.e. zero tillage, which eliminates the adverse effects of tillage and retains soil resources and eventually contributes to sustainable agriculture.
\end{abstract}

Keywords: Zero tillage, conventional tillage, nutrients available, sustainable farming

\section{Introduction}

As they save energy and provide optimal soil conditions for sustainable crop production and reduced cultivation costs, conservation tillage practises like zero tillage or limited soil disturbance and residue retention on the soil surface are becoming economically and ecologically viable options. Better root growth and efficient use of water and nutrients can be encouraged by improved soil conditions. Long-term conservation tillage improves the status of soil organic carbon and modifies soil pore geometry that ultimately affects basic physical parameters such as bulk density, aggregate stability, capacity for water retention, etc., and the status of soil fertility. The effects of conservation tillage, however, are highly variable across climate, soil type and depth, cropping method, and vary widely with the system's adoption period. In order to feed the growing population on a sustainable basis without degrading natural resources (soil and water) and the climate, there is a need to increase farm productivity and total food production. It is estimated that by 2050 the world population will be about 9.8 billion and 37 percent of which will reside in China and India (UN, 2017) ${ }^{\text {[60] }}$, requiring an estimated 59-98 percent rise in food demand (Valin et al. 2014) ${ }^{[61]}$, placing more pressure on natural resources. Although green revolution technologies implemented in the country during 1966-67 led to food protection, intensive cropping, insufficient and imbalanced use of fertilisers, high yielding crop varieties, use of heavy machinery, excess lawning, etc., for more than five decades resulted in degradation of soil health, decrease in organic matter in the soil, decrease in chemical and physical soil, etc. Organic soil carbon is considered an important soil quality index and is considered a key factor in cycling plant nutrients and improving the chemical properties of the soil. Moreover, nowadays, due to industrialization and other anthropogenic activities, there is a growing concern about elevated concentrations of $\mathrm{CO} 2$ in the atmosphere. Almost three times the carbon contained in vegetation is contained in the upper $30 \mathrm{~cm}$ soil layer (Powlson et al. 2012) ${ }^{[46]}$, which is considered most prone to CO2 loss. 
Estimates of total $\mathrm{C}$ sequestration capacity in the world's soils, however, vary widely from 0.4 to $1.2 \mathrm{Gt} \mathrm{C}$ year-1. There is also the ability to increase the stock of $\mathrm{C}$ in soils (FAO, 2011). There is therefore a increasing concern about the implementation of technologies and management practises that have the potential to increase the content of organic carbon in the soil. Conservation agriculture (CA) has been found to have sufficient capacity to improve soil organic carbon and soil productivity. In this era of climate change, the $\mathrm{CA}$ is a resource-saving agricultural crop production system that aims to achieve reasonable benefit along with high and sustained levels of production while at the same time protecting the environment (FAO, 2010) ${ }^{[21]}$. The three interlinked principles of conservation agriculture are: I continuous minimum mechanical soil disturbances, (ii) preservation of permanent organic soil coverage, and (iii) diversified crop rotations (FAO 2010) ${ }^{[21]}$. One component of conservation agriculture, zero tillage, refers to soil management systems that result in crop residues covering at least 30 percent of the soil surface (Jarecki and Lal, 2003) ${ }^{[30]}$. Tillage activity, on the other hand, is synonymous with soil ploughing with some tools and implements to manage weeds and build a favourable soil tilth for proper seed germination, emergence of seedling, and plant establishment and development (Ahn and Hintze, 1990) ${ }^{[1]}$. Tillage has been found to compact sub-surface soil in the current mechanised agriculture scenario, limiting root penetration and production, nutrient and water availability, and thus plant growth and yield. The mechanical inversion of the soil does not take place when the tillage is not used over the years, and hence the soilplant system enters a physical balance. In addition, as a result of reduced soil organic carbon, intensive tillage operations typically increase soil erosion, environmental contamination and soil degradation (Srinivasan et al. 2012) ${ }^{[53]}$. With the advent of herbicides for weed control, several scientists have advocated the adoption of zero tillage to minimise organic matter oxidation, sub-surface compaction and better soil condition for root penetration and proliferation, increasing the availability of nutrients and water resulting in better growth and yield of pants. Conservation tillage is now considered a promising alternative to conventional tillage practise (Teklu, 2011) ${ }^{[56]}$. Conservation tillage is a promising alternative to traditional tillage practise.

\section{Impact of zero tillage on soil chemical properties Soil pH and EC}

One of the significant factors determining soil fertility is $\mathrm{pH}$, which may, however, be highly influenced by cultivation and crop residue management. For plant growth and development, soil reaction shows a clear assembly with nutrient availability. Long-term zero tillage adoption results in surface soil acidification that further impacts the supply and distribution within the rhizosphere of other nutrients. A substantial reduction of $\mathrm{pH}$ observed on silt loam soil at the upper soil of $0-7.5 \mathrm{~cm}$ under zero tillage (Dick et al. 1986) ${ }^{[18]}$. Soil acidity with zero tillage was found in Kentucky due to decomposition of organic residues at the surface with subsequent leaching into mineral soil of the resulting organic acids (Blevins et al. 1977) ${ }^{[12]}$. Kumar and Yadav (2005) ${ }^{[33]}$ reported a marginal decline in soil $\mathrm{pH}$ relative to the initial traditional tillage values. However, the major impact of tillage on soil $\mathrm{pH}$ in both loam sand and sandy loam soil was not observed by Singh and Singh (2001) [51]. Due to the increased water movement in the soil and improved soil aggregate growth, Chatterjee and Lal (2009) ${ }^{[16]}$ observed lower electrical conductivity of soil under the zero tillage method compared with traditional tillage. In traditional tillage practises, the rise in $\mathrm{pH}$ may be attributed to more organic matter oxidation due to intensive tillage, which causes more soil $\mathrm{CO}_{2}$ evolution and thus increased surface and subsurface soil $\mathrm{pH}$. Organic matter decomposition under traditional tillage has induced organic acid production and increased $\mathrm{pH}$ (Hulugalle and Weaver, 2005) [29]. Miyazawa et al. (1993) [39] reported that by returning crop residues to the land, soil can be protected from acidification. But under zero tillage, there are contradictory results regarding $\mathrm{pH}$. Karlen et al. (1994) ${ }^{[31]}$ and Dick et al. (1986) ${ }^{[18]}$ reported that acidification was caused by zero tillage with a substantial reduction in $\mathrm{pH}$. This reduction in EC under zero tillage may be due to leaching of salts due to increased movement of water and plant uptake (Chatterjee and Lal, 2009) ${ }^{[16]}$

\section{Soil organic carbon}

In soil fertility, soil organic carbon (SOC) plays a crucial role. Due to its crucial role in the chemical, physical and biological properties of the soil, it is an important measure of soil fertility and productivity (Gregorich and Janzen, 1994) ${ }^{[24]}$. For sustainable agro-ecosystems, maintenance of a satisfactory level of SOM is therefore necessary. There are two ways of increasing SOC: (1) increasing the input of C, or (2) reducing the loss and decomposition of SOC. By implementing residue management and using conservation tillage, carbon production can be increased and decomposition decreased (no tillage or limited tillage). However, due to elevated background $\mathrm{C}$ content and its temporal and spatial variability, short and medium-term SOC shifts are difficult to detect (Bosatta and Agren, 1994) ${ }^{[13]}$. Increased atmospheric greenhouse gas concentrations and consequent climate change have contributed to an overriding interest in organic carbon sequestration in agricultural soils. SOC is the primary component of soil organic matter (SOM) and is formed on or below the soil surface by the decomposition of different organic materials. The rate of SOM turnover and decomposition is largely determined by the interactions between different components of the soil (physical, chemical and biological) and the environment, such as temperature and humidity (Taylor et al. 2009) ${ }^{[55]}$. The SOC level can be sustained or even increased by better farming management practises along with other added benefits in terms of better physical condition, fertility and soil water conservation (Stockmann et al. 2013) ${ }^{[54]}$. Tillage operations that are mainly conducted for the preparation of seed fields, weed control, introduction of residues, play a dominant role in reducing the level of SOC and altering the physical conditions of the soil (Victoria et al. 2012) ${ }^{[62]}$. Compared to normal movement of soluble, particulate or colloidal carbon, tillage physically integrates the carbon as crop residue into the soil. However, the soil aggregates are killed by continuous traditional tillage and the covered SOC is exposed to the atmosphere, which then undergoes rapid decomposition by aerobic micro organisms (Al-Kaisi and Yin, 2005) ${ }^{[4]}$. It has been estimated that traditional tillage activities have removed about 75 percent of the SOC stock of native land (Lal et al. 2007) ${ }^{[36]}$. The SOC level of the soil can be increased by zero tillage, which is a mitigation choice for the level of $\mathrm{CO} 2$ in the atmosphere. This mechanism is called 'carbon sequestration' and the source-sink relationship of carbon in cultivated land is influenced by various agricultural management practises (Lin et al. 2002) ${ }^{[37]}$. In C-sequestration, SOC turnover time may have a dominant function and is influenced by soil 
mineralogy and climatic conditions (rainfall, temperature and radiation). In the form of cover crop under zero tillage, residue mulch or live mulch improves the degree of SOC and improves the process of $\mathrm{C}$-sequestration. Minimal zero tillage soil disturbance favoured the formation of macro-aggregates and covered the intra-aggregate SOC (Six et al. 2000a) ${ }^{552}$

]. Owing to slow decomposition, crop residue maintained on the soil surface increased the SOC amount (Guo et al. 2015) [25]. Conservation agriculture had a beneficial impact on biological activities and/or physical structure development such as earthworm macro-aggregates, suggesting a special SOC dynamics (Brouder and Gomez-Macpherson, 2014) ${ }^{[14]}$. Due to higher oxidation rates, the tillage is known to cause rapid loss of SOM material. This results in a degradation of the physical properties of the soil and a potential decline in crop production in the long term (Du Preez et al. 2001) ${ }^{[20]}$. With the period of conversion from traditional tillage to zero tillage, soil organic $\mathrm{C}$ was found to increase, especially in a few centimetres of surface soil (Hermle et al. 2008) ${ }^{\text {[27]. In }}$ shallow or zero tillage, an accumulation of organic matter near the soil surface is typically observed due to a decrease in ploughing depth (Moreno et al. 2006) ${ }^{[40]}$. Even after years of traditional tillage, the implementation of zero tillage management led to a rise in SOC across the Great Plains in a wide range of soils and climates (Baker et al. 2007) ${ }^{[8]}$. In arid and semi-arid areas where SOM material is often lost because of its harsh climatic conditions, conservation tillage has improved the organic matter content and water storage (Du Preez et al. 2001) ${ }^{[20]}$. In semi-arid regions, however, variations in soil organic $\mathrm{C}$ between traditional and zero tillage systems are typically limited since conventional tillage is less intensive and shallower than in wet regions (Unger, 1991) ${ }^{[59]}$. In zero and shallow-tilled plots compared to traditional tillage, Gosai et al. (2009) ${ }^{[23]}$ recorded greater organic matter content. After 11 years of continuous cultivation, the carbon storage of zero tillage at $0-15 \mathrm{~cm}$ surpassed that of traditional tillage by $0,1.6$ and $3.9 \mathrm{Mg}$ ha-1 in sandy loam, silt loam and clay loam soils, respectively (Campbell et al. 1996a) ${ }^{[15]}$. Failure to increase SOC sequestration by zero tillage practises relative to traditional tillage systems was also stated (Ogle et al. 2005) ${ }^{[41]}$. Zero tillage has increased surface SOC content in many finetextured soils at the cost of SOC deposited within the rooting zone (Kay and VandenBygaart, 2002) ${ }^{[32]}$. Conservation tillage, such as zero tillage, has the ability to sustain both soil fertility and crop fertility as it has a major effect on the organic carbon content of the soil due to crop residue retention. Madari et al. (2005) ${ }^{[38]}$ found that, with larger aggregates and more soil organic carbon, zero tillage with residue cover had greater aggregate stability. By implementing zero tillage, higher soil organic carbon sequestration has also been observed (Panday et al. 2008) ${ }^{[42]}$. After rice and wheat harvesting, the soil organic carbon content in the $0-15 \mathrm{~cm}$ soil depth was higher under zero tillage than under traditional tillage, but soil organic carbon content remained almost unchanged in both traditional and zero tillage in the $15-30 \mathrm{~cm}$ soil layer after 4 years of cropping (Bhattacharyya et al. 2008) ${ }^{[11]}$. Hooker et al. (2005) [28] also discovered that residue control had little impact on SOC in the surface soil layer $(0-5 \mathrm{~cm})$ during tillage treatment. Tillage appeared to decrease the SOC material, although, as opposed to tomold board ploughed treatments, only zero till combined with stover return to the soil resulted in an increase in SOC in the surface layer. Improved land and crop management methods have improved SOC relative to traditional methods, such as decreased tillage (Andruschkewitsch et al. 2013) ${ }^{[5]}$. Long-term zero laying increased the surface layer soil carbon stock by 19.0, 34.7 and 38.8 percent over traditional laying in sandy loam, loam and clay loam soil over 15 years (Singh et al. 2014) ${ }^{[49]}$. Dong et al. (2009) ${ }^{[19]}$ stated that, relative to the total SOC, the impact of tillage and residue management was greater on SOC fractions, such as dissolved organic $\mathrm{C}$, microbial biomass $\mathrm{C}$ and particulate organic matter $\mathrm{C}$. Compared to traditional practises, improved crop management practises, such as zero tillage and straw mulch techniques, will increase the SOC and the SOC fractions (Andruschkewitsch et al. 2013) ${ }^{[5]}$. Zotarelli et al. (2005) ${ }^{[66]}$ reported that by influencing soil aggregates and aggregate-associated $\mathrm{C}$, soil disturbance showed major influences on SOC safety. Freixo et al. (2002) ${ }^{[22]}$ found that topsoil organic carbon of $0-5 \mathrm{~cm}$ decreased by 60 percent after 13 years of traditional tillage farming, whereas zero tillage conditions decreased 43 percent. Under zero tillage, soil organic $\mathrm{C}$ storage is always greater than traditional tillage due to residue accumulation at the soil surface (Piovanelliet al. 2006) ${ }^{[45]}$. Soils administered with ZT change SOM, microbial species and nutrient availability and their roles (Thomas et al. 2007) ${ }^{[58]}$. Residues on the soil surface are maintained by the no tillage system and the SOC has therefore increased compared to intensive tillage systems (Kumar et al. 2012) ${ }^{[34]}$.

\section{Available nutrients (N, P, K and micronutrients) in soil and their uptake by plants}

Zero tillage plays a major role in the supply of nutrients and their uptake by plants. Nutrient availability near the soil surface was improved by the Zero tillage (Bhatt et al. 2016; Antil and Narwal, 2007) ${ }^{[10,6]}$. The addition of more organic matter in the form of crop residues, which is the main source of nitrogen and the presence of more microbes and microbial activities, has resulted in higher nitrogen availability under zero tillage. Alijani et al. (2012) ${ }^{[3]}$ stated that an increase in soil nitrogen was caused by reduced tillage. Conservation tillage activities such as zero tillage have increased the supply of nitrogen, according to Habtegebrial et al. (2007) ${ }^{[26]}$. With deeper layers, the nitrogen available has decreased (Sharma $e t$ al. 2015) ${ }^{[48]}$. In comparison to pearl millet, the $\mathrm{N}$ uptake was higher by 16.7 and 13.1 percent and $\mathrm{P}$ uptake by 22.2 and 16.5 percent when wheat was grown after cowpea and cluster bean, respectively. Compared to wheat grown after pearl millet al.one, Balyan (1997) ${ }^{[9]}$ observed higher $\mathrm{N}$ uptake in wheat grown after legume crops either alone or as an intercrop during kharif. The amount of potassium content in maize was 0.26 and $0.26 \mathrm{Cmol} / \mathrm{kg}$, respectively, for surface and zero tillage (Ali, 2018) ${ }^{[2]}$. N and P uptake by wheat sown after cowpea and cluster bean was statistically at par with each other and significantly greater after pearl millet than that raised bed (Singh et al. 2003) ${ }^{[50]}$. Parihar et al. (2018) ${ }^{[43]}$ stated that it could have improved soil fertility and improved crop growth, yield, and nutrient content by using legumes as the preceding crop. Recycling of nutrients from sub-surface to surface layers and enhanced nutrient availability in the rhizosphere of shallow rooted crops are caused by the rotation of deep-rooted legumes in the cropping systems. Due to the insertion of legumes into cropping systems, Aziz et al. (2015) [7] and Parihar (2014) [43] have also recorded increased nitrogen content. Das et al. (2014) ${ }^{[17]}$ published comparable findings. The higher availability of zero tillage phosphorus was due to the addition of more organic matter in the form of crop residues, which increased the availability of phosphorus 
due to the release of organic acids during organic material decomposition. Alijani et al. (2012) [3] stated that soil phosphorus was increased by reduced tillage. Conservation tillage activities such as zero tillage have increased the availability of phosphorus, according to Habtegebrial et al. (2007) ${ }^{[26]}$. Sharma et al. (2015) ${ }^{[48]}$ and Kumar et al. (2012) ${ }^{[34]}$ have reported the decrease in usable phosphorus with soil depth. Increased phosphorus content due to the insertion of legumes into cropping systems has also been documented by Aziz et al. (2015) ${ }^{[7]}$. Higher soil organic matter can be due to the rise in usable phosphorus under zero tillage practises. Under zero tillage activities, Kushwah et al. (2016) [35] observed greater usable phosphorus. Similar to the N and P available, greater potassium abundance under zero tillage was due to the addition of more organic matter in the form of potassium-sourced crop residues. Alijani et al. (2012) ${ }^{[3]}$ stated that an increase in soil potassium was caused by reduced tillage. Under zero tillage activities, Kushwah et al. (2016) ${ }^{[35]}$ and Roldan et al. (2003) [47] observed greater usable potassium. Higher soil organic matter can be due to the rise in usable potassium under zero tillage practises. Crop residue has had a beneficial impact on available soil potassium (Yadvinder-Singh and Sidhu, 2014) ${ }^{[65]}$. In the $0-40 \mathrm{~cm}$ soil layer with residue retention, Wei et al. (2015) noted an increase in usable potassium. Similarly, in the $0-15 \mathrm{~cm}$ soil layer under zero tillage and maize residue retention, Villamil and Nafziger (2015) [63] found significantly higher exchangeable potassium than traditional tillage and without residue in the continuous maize cropping system. With deeper layers, the potassium available has decreased (Sharma et al. 2015) ${ }^{[48]}$. The addition of more organic matter in the form of crop residues, which are the main source of Fe, Mn and $\mathrm{Zn}$, resulted in higher availability of micronutrients (Fe, Mn and $\mathrm{Zn}$ ) except for $\mathrm{Cu}$ under zero tillage. In contrast with traditional tillage, crop residues under zero tillage led to greater organic matter addition under zero tillage. Soil moisture was higher under zero tillage, which may be an explanation for the greater availability of these nutrients

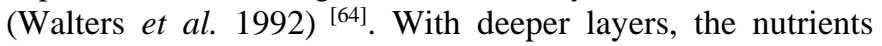
available have decreased (Sharma et al. 2015; Kumar et al. 2012) ${ }^{[48,34]}$.

\section{Conclusion}

Finally, we concluded that long-term practises of zero tillage could boost the chemical properties of the soil and conserve soil resources for sustainable agriculture. Due to the unparalleled increase in the world population and rapid economic growth, the number of food-insecure individuals may increase. In addition, due to growth in popularity, soil depletion, urbanisation, and other competing uses, the per capita cropland region is also declining. The stratagem is therefore to balance food production demand with the need for soil regeneration and reduction of the environmental footprint of agroecosystems. By following sustainable practises such as zero tillage, this can be done. The strategy is to improve soil quality by restoring SOC stock, improving the productivity of inputs for usage, narrowing the yield gap and implementing sustainable agroecosystem intensification systems. The 1960s Green Revolution improved food production, but due to intensive cultivation, heavy farm machinery, excessive irrigation usage, and indiscriminate use of fertilisers and pesticides, there were strong confrontational impacts on the climate, including depletion of SOC stock, increased risks of soil erosion and salinization degradation, and deterioration of physical properties of the soil. The goal is to generate more from less soil, less water usage, less fertiliser and pesticide production, and less energy consumption. In order to transform scientific information into effect, the much needed paradigm change will also entail defining and enforcing effective policies. Zero tillage, properly applied, is one of the best solutions with the ability to enhance all chemical properties of the soil, preserve soil and water and retain productivity. By designing site-specific packages and informing the agricultural community and the general public about the merits of zero tillage and stewardship of soil resources, its implementation can be strengthened.

\section{References}

1. Ahn PM, Hintz B. No tillage, minimum tillage, and their influence on soil physical properties. In IBSRAM Proceedings (Thailand) 1990. IBSRAM.

2. Ali MH. Soil - a media of plant growth (Chapter-4). In: Fundamentals of Irrigation \& On-farm Water Management, Springer 2018;1:107-218.

3. Alijani K, Bahrani M, Kazemeini A. Short-term responses of soil and wheat yield to tillage, corn residue management and nitrogen fertilization. Soil \& Tillage Research 2012;124:78-82.

4. Al-Kaisi MM, Yin X. Tillage and crop residue effects on soil carbon and carbon dioxide emission in corn-soybean rotations. Journal of Environmental Quality 2005;34:437445.

5. Andruschkewitsch R, Geisseler D, Koch HJ, Ludwig B. Effects of tillage on contents of organic carbon, nitrogen, water-stable aggregates and light fraction for four different long-term trials. Geoderma, 2013;192:368377.

6. Antil RS, Narwal RP. Role of integrated nutrient management for sustainable soil health and crop productivity under various cropping systems. Indian Journal of Fertilizers 2007;3(9):111-121.

7. Aziz I, Bangash N, Mahmood T, Islam KR. Impact of notill and conventional tillage practices on soil chemical properties. Pakistan Journal of Botany 2015;47:297-303.

8. Baker JM, Ochsner TE, Venterea RE, Griffis TJ. Tillage and soil carbon sequestration. What do we really know? Agric Ecosyst Environ 2007;118:1-5.

9. Balyan JS. Production potential and nitrogen uptake by succeeding wheat (Triticum aestivum) under different cropping sequences. Indian Journal of Agronomy 1997;42:250-252.

10. Bhatt R, Kukal SS, Busari MA, Arora S, Yadav M. Sustainability issues on rice-wheat cropping system. International Soil and Water Conservation Research 2016;4:64-74.

11. Bhattacharyya R, Kundu S, Pandey S, Singh KP, Gupta HS. Tillage and irrigation effects on crop yields and soil properties under rice-wheat system of the Indian Himalayas. Agricultural Water Management 2008;95:993-1002.

12. Blevins RL, GW Thomas, PL Cornelius. Influence of notillage and nitrogen fertilization on certain soil properties after five years of continuous corn. Agronomy journal 1977;69:383-386.

13. Bosatta DA, Agren GI. Theoretical analysis of microbial biomass dynamics in soils. Soil Biol. Biochem 1994;26:143-148.

14. Brouder SM, Gomez-Macpherson H. The impact of conservation agriculture on smallholder agricultural 
yields: a scoping review of the evidence. Agriculture, Ecosystems \& Environment 2014;187:11-32.

15. Campbell CA, McConkey BG, Zentner RP, Selles F, Curtin D. Tillage and crop rotation effects on soil organic $\mathrm{C}$ and $\mathrm{N}$ in a coarse-textured Typic Haploboroll in southwestern Saskatchewan. Soil \& Tillage Research 1996a;37:3-14.

16. Chatterjee A, Lal R. On farm assessment of tillage impact on soil carbon and associated soil quality parameters. Soil and Tillage Research 2009;104(2):270-277.

17. Das A, Ghosh PK, Lal R, Saha R, Ngachan S. Soil quality effect of conservation practices in maizerapeseed cropping system in eastern Himalaya. Land Degradation and Development 2014. DOI: 10.1002/ldr.2325.

18. Dick WA, Van Doren DM, Triplettt GB, Henry JE. Influence of long term tillage and rotation combinations on crop yields and selected soil parameters. II. Results obtained for a Typic Fragiudalf soil. Ohil Agriculture Research \& Development Centre 1986;1181:1-34.

19. Dong W, Hu C, Chen S, Zhang Y. Tillage and residue management effects on soil carbon and $\mathrm{CO}_{2}$ emmision in a wheat-maize double-cropping system. Nutrient Cycling in Agroecosystems 2009;83:27-37.

20. Du Preez CC, Steyn JT, Kotze E. Long-term effects of wheat residue management on some fertility indicators of a semi-arid Plinthosol. Soil \& Tillage Research 2001;63:25-33.

21. FAO. What is conservation agriculture 2010; FAO CAwebsite http://www.fao.org/ag/ca/1a.html. Accessed on 13/08/2019.

22. Freixo AA, Machado PL, Santos HP. Soil organic carbon and fractions of Rhodic Ferralsol under the influence of tillage and crop rotation systems in Southern Brazil. Soiland Tillage Research 2002;64:221-230.

23. Gosai K, Arunachalam A, Dutta BK. Influence of conservation tillage on soil physicochemical properties in a tropical rainfed agricultural system of northeast India. Soil \& Tillage Research 2009;105:63-71.

24. Gregorich EG, Janzen HH. Storage of soil carbon in the light fraction and macro-organic matter. In: CRC press 1994, 167-190.

25. Guo LJ, Zhang ZS, Wang DD, Li CF, Cao CG. Effects of shortterm conservation management practices on soil organic carbon fractions and microbial community composition under a rice-wheat rotation system. Biology and Fertility of Soils 2015;51:65-75.

26. Habtegebrial K, Singh BR, Haile M. Impact of tillage and nitrogen fertilization on yield, nitrogen use efficiency of tef (Eragrostis tef (Zucc.) Trotter) and soil properties. Soil and Tillage Research 2007;94:55-63.

27. Hermle S, Anken T, Leifeld J, Weisskopf P. The effect of the tillage system on soil organic carbon content under moist, cold-temperate conditions. Soil \& Tillage Research 2008;98:94-105.

28. Hooker BA, Morris TF, Peters R, Cardon ZG. Long-term effects of tillage and corn stalk returnon soil carbon dynamics. SoilScience Society of American Journal 2005;69:188-196.

29. Hulugalle NR, Weaver TB. Short-term variations in chemical properties of Vertisols as affected by amounts, carbon/nitrogen ratio, and nutrient concentration of crop residues. Communications in Soil Science and Plant Analysis 2005;36:1449-1464.
30. Jarecki MK, Lal R. Crop management for soil carbon sequestration. Critical Reviews in Plant Sciences 2003;22:471-502.

31. Karlen DL, Wollenhaupt NC, Erbach DC, Berry EC, Swan JB, Eash NS et al. Crop residue effects on soil quality following 10-years of no-till corn. Soil \& Tillage Research 1994;31:149-167.

32. Kay BD, VandenBygaart AJ. Conservation tillage and depth stratification of porosity and soil organic matter. Soil \& Tillage Research 2002;66:107-118.

33. Kumar A, Yadav DS. Effect of zero and minimum tillage in conjunction with nitrogen management in wheat (Triticum aestivum) after rice (Oryza sativa.). Indian Journal of Agronomy 2005;50(1):54-55.

34. Kumar S, Dahiya R, Kumar P, Jhorar BS, Phogat VK. Long-term effect of organic materials and fertilizers on soil properties in pearl millet-wheat cropping system. Indian Journal of Agricultural Research 2012;46(2):16166.

35. Kushwah SS, Reddy DD, Somasundaram J, Srivastava S, Khamparia RS. Crop residue retention and nutrient management practices on stratification of phosphorus and soil organic carbon in the soybean-wheat system in Vertisols of Central India. Communication in Soil Science and Plant Analysis 2016;47:2387-2395.

36. Lal R, Reicosky DC, Hanson JD. Evolution of the plow over 10,000 years and the rationale for no-till farming. Soil and Tillage Research 2007;93:1-12.

37. Lin E, Li YE, Guo L. Carbon emissions and sinks in agro-ecosystems of China. Science in China. Series C, Life Sciences 2002;45:30-39.

38. Madari B, Machado PL, Torres OA, de Andrade E, Valencia AL. No tillage and crop rotation effects on soil aggregation and organic carbon in a Rhodic Ferralsol from southern Brazil. Soil \&Tillage Research 2005;80:185-200.

39. Miyazawa M, Pawan MA, Calegari A. Effect of plant material on soil acidity. Revista Brasileira de Ciencia do Solo 1993;17:411-416.

40. Moreno F, Murillo JM, Pelegrín F, Girón IF. Long-term impact of conservation tillage on stratification ratio of soil organic carbon and loss of total and active $\mathrm{CaCO} 3$. Soil \& Tillage Research 2006;85:86-93.

41. Ogle SM, Breidt FJ, Paustian K. Agricultural management impacts on soil organic carbon storage under moist and dry climatic conditions of temperate and tropical regions. Biogeochemistry 2005;72:87-121.

42. Panday SC, Singh RD, Saha S, Singh KP, Prakash V, Kumar A, et al. Effect of tillage and irrigation on yield, profitability, water productivity and soil health in ricewheat cropping systems in north-west Himalayas. Indian Journal of Agricultural Sciences 2008;78(12):1018-22.

43. Parihar MD. Studies on Green House Gas Emissions and Carbon Sequestration Under Conservation agriculture in Maize Based Cropping Systems. Department of Agronomy, CCS HAU, Hisar 2014.

44. Parihar CM, Yadav MR, Jat SL, Singh AK, Kumar B, Pooniya V, et al. Long-Term Conservation Agriculture and Intensified Cropping Systems: Effects on Growth, Yield, Water, and Energy-use Efficiency of Maize in Northwestern India. Pedosphere 2018;28(6):952-963.

45. Piovanelli C, Gamba C, Brandi G, Simonini S, Batistoni E. Tillage choices affect biochemical properties in the soil profile. Soil \& Tillage Research 2006;90:84-92. 
46. Powlson DS, Bhogal A, Chambers BJ, Coleman K, Macdonald AJ. The potential to increase soil carbon stocks through reduced tillage or organic material additions in England and Wales: A case study. Agricultural Ecology and Environment 2012;146:23-33.

47. Roldan A, Caravaca F, Hernandez MT, Garcia C, Sánchez-Brito C, Velasquez M, et al. Notillage, crop residue additions, and legume cover cropping effects on soil quality characteristics under maize in Patzcuaro watershed (Mexico). Soil \& Tillage Research 2003;72:65-73.

48. Sharma VK, Pandey RN, Sharma BM. Studies on long term impact of STCR based integrated fertilizer use on pearl millet (Pennisetum glaucum)-wheat (Triticum aestivum) cropping system in semi-arid condition of India. Journal of Environmental Biology 2015;36(1):241.

49. Singh A, Phogat VK, Dahiya R, Batra SD. Impact of long-term zero till wheat on soil physical properties and wheat productivity under rice-wheat cropping system. Soil \& Tillage Research 2014;140:98-105.

50. Singh J, KP Singh, SS Yadav, JS Yadav. Effect of preceding crops and fertility levels on wheat (Triticum aestivum) in light-textured soil. Indian Journal of Agronomy 2003;48:86-88.

51. Singh M, Singh VP, Reddy KS. Effect of integrated use of fertilizer nitrogen and farmyard manure or green manure on transformation of $\mathrm{N}, \mathrm{K}$ and $\mathrm{S}$, and productivity of rice-wheat system on a vertisol. Journal of the Indian Society of Soil Science 2001;49:430-435.

52. Six JAET, Elliott ET, Paustian K. Soil macroaggregate turnover and microaggregate formation: a mechanism for $\mathrm{C}$ sequestration under no-tillage agriculture. Soil Biology \& Biochemistry 2000a;32:2099-2103.

53. Srinivasan V, Maheswarappa HP, Lal R. Long term effects of topsoil depth and amendments on particulate and non-particulate carbon fractions in a Miamian soil of Central Ohio. Soil \& Tillage Research 2012;121:10-17.

54. Stockmann U, Adams MA, Crawford JW, Field DJ, Henakaarchchi N, Jenkins M, et al. The knowns, known unknowns and unknowns of sequestration of soil organic carbon. Agriculture, Ecosystems \& Environment 2013;164:80-99.

55. Taylor LL, Leake JR, Quirk J, Hardy K, Banwart SA, Beerling DJ, et al. Biological weathering and the long-term carbon cycle: integrating mycorrhizal evolution and function into the current paradigm. Geobiology 2009;7171-191.

56. Teklu Er K. Tillage effects on physical qualities of vertisol in the central highlands of Ethiopia. African Journal of Environmental Science and Technology 2011;5:1008-1016.

57. Thomas GW, Haszler GR, Blevins RL. In Proceedings of The effects of organic matter and tillage on maximum compactability. Conservation Farming A Focus on 1995.

58. Thomas GA, Dalal RC, Standley J. No-till effects on organic matter, $\mathrm{pH}$, cation exchange capacity and nutrient distribution in a Luvisol in the semi-arid subtropics Soil \& Tillage Research 2007;94:295-304.

59. Unger PW. Organic matter, nutrient, and $\mathrm{pH}$ distribution in no-and conventional-tillage semiarid soils. Agronomy Journal 1991;83:186-189.

60. United Nations. World Population Prospects: The 2017 Revision. United Nations, New York 2017.

61. Valin H, Sands RD, van der Mensbrugghe D, Nelson GC, Ahammad H, Blanc E, et al. The furure of food demand: understanding differences in global economic models. Agricultural Economics 2014;45:51-67.

62. Victoria R, Banwart S, Black H, Ingram J, Joosten H, Milne E, Nollemeyer E, et al. The benefits of soil carbon. Foresight chapter in UNEP Yearbook 2012, 19-33.

63. Villamil MB, Nafziger ED. Corn residue, tillage and nitrogen rate effects on soil carbon and nutrient stocks in Illinois. Geoderma 2015;253:61-66.

64. Walters DT, Aulakh MS, Doran JW. Effects of soil aeration, legume residue, and soi] texture on transformations of macro- and micronutrients in soils. Soil Science, 153:100-107. Water Quality 1992, 34-40.

65. Yadvinder-Singh, Sidhu HS. Management of cereal crop residues for sustainable rice- wheat production system in the Indo-Gangetic plains of India. Proceedings of the Indian National Science Academy 2014;80:95-114.

66. Zotarelli L, Alves BJR, Urquiaga S, Torres E, Dos Santos $\mathrm{HP}$, Paustian K, et al. Impact of tillage and crop rotation on aggregate-associated carbon in two oxisols. Soil Science Society of America Journal 2005;69:482-491. 